\title{
"Distribution And Daily Activity Of Collared Dove (Streptopelia Decaocto) In And Around Sikar (Rajasthan), India"
}

\author{
Dr. Maha Singh ${ }^{1}$ P.R.Ojha ${ }^{2}$ \\ ${ }^{1}$ Lecturer in zoology, Govt. S. K. (PG) College, Sikar (Rajasthan) \\ P.No.30, RamawatNagar, KissanColony, Nawalgarh Road, Sikar332001 \\ ${ }^{2}$ IASE University, Sardarsharar, Churu (Rajasthan).
}

\begin{abstract}
Collared Dove is native species of Asia and Europe. It is found in throughout the drier portions of the Indian Union. Collared Dove native to India, Sri Lanka and Myanmar. It is not migratory bird but it is strongly dispersive bird. Collared Dove lives in urban and rural areas, farmlands, parks, gardens, open fields and grain stores. Collared Dove preferred as roosting plant species like as Khejri (Prosopis cineraria) and Babool (Acacia nilotica) and also retires on them during the midday heat. It is found in abundant in the neighborhood of human habitations, and freely enters gardens and bungalow verandas. Collared Dove mainly feeds on spreading seeds on the ground, but also feed on buds, soft fruits and garbage. It is freely feeds near to human habitation. Collared Dove feeds on the ground in large flocks around farms and grain stores. It is gregarious species and flocks will form where there are food supplies such as grain (its main food) as well as seeds and shoots. Collared Dove drinks by sucking and don't need to put the head back to swallow. The breeding season of Collared Dove is in March to late October but breeding occurs throughout the year when abundant food is available, though only rarely in winter. Collared Dove preferred as nesting plant species like as Khejri (Prosopis cineraria), Kikar (Acacia nilotica) and Neem (Azardirecta indica). The maximum population was recorded during the rainy season i.e. the months of July, August and September. Maximum activities performed by the collared dove in the early morning to late morning (5.00 AM to $11.00 \mathrm{AM})$ and less activities performed in afternoon to evening (3.30 PM to 7.00 PM).
\end{abstract}

KEYWORDS: - Collared Dove, Daily activity, Roosting, Sikar, Spatial arrangement.

\section{INTRODUCTION}

The present study has been under taken in the North-Eastern part of Rajasthan in and around the Sikar city. Collared Dove also known as Eurasian Collared Dove because it is native species of Asia and Europe. It is found in throughout the drier portions of the Indian Union. Collared Dove native to India, Sri Lanka and Myanmar. Recently it is introduced in North America also. Collared Dove is not migratory bird but it is strongly dispersive bird. In the last century it is one of the great colonizers of the bird world. Collared Dove lives in urban and rural areas, farmlands, parks, gardens, open fields and grain stores. Collared Dove preferred as roosting plant species like as Khejri (Prosopis cineraria) and Babool (Acacia nilotica) and also retires on them during the midday heat. It is found in abundant in the neighborhood of human habitations, and freely enters gardens and bungalow verandas. Collared Dove mainly feeds on spreading seeds on the ground, but also feed on buds, soft fruits and garbage. Collared Dove feeds on the ground. They feed in large flocks around farms and grain stores. It is seen solitary, but often in pairs. Collared Dove drinks by sucking and don t need to put the head back to swallow. The breeding season of Collared Dove is in March to late October but breeding occurs throughout the year when abundant food is available, though only rarely in winter. Collared Dove preferred as nesting plant species like as Khejri (Prosopis cineraria), Kikar (Acacia nilotica) and Neem (Azardirecta indica).

\section{MATERIALS AND METHODS}

Sikar is located between $27^{\circ} 37^{\prime} \mathrm{N}$ to $27.62^{\circ} \mathrm{N}$ latitude and $75^{\circ} 09^{\prime} \mathrm{E}$ to $75^{\circ} 15^{\prime} \mathrm{E}$ longitude. The average elevation from mean sea level is 427 meters (1400 feet). The district boundaries of Sikar are close with Jhunjhunu district in the north, Jaipur district in the east and southeast, Haryana state in the northeast, Churu district in the west and northwest and Nagaur district in the southwest. The climate of Sikar is characterized with hot summers, extremely cold winters, scanty rainfall and a general dryness of the air except in the brief monsoon season. The average rainfall of Sikar in last twenty year (1991 to Aug.2010) is $216.23 \mathrm{~mm}$. (Meteorological Department Sikar (Rajasthan) India. The average maximum and minimum temperature of Sikar in summer season is around $40.0^{\circ} \mathrm{C}$ and $27.0^{\circ} \mathrm{C}$ respectively whereas average maximum 
and minimum temperature during winter season is $30.0^{\circ} \mathrm{C}$ and $10.0^{\circ} \mathrm{C}$ respectively. The minimum temperature sometimes may fall up to $-2^{\circ} \mathrm{C}$ or more during the winters.

\subsection{Plan of field work: -}

The study was conducted over a period of 24 months (September, 2008 to August, 2010). Regular weekly field trips were made throughout the period. Observations for avian diversity and population dynamics were taken in two sessions in a day - Morning session of four hour duration (5.00 to $9.00 \mathrm{AM}$ ) and evening session of three hour duration (3.30 to $6.30 \mathrm{PM})$ and some observations were taken in noon and afternoon sessions. The counting was done by Stationary point count method. Stationary point counts have special value in studies of bird-habitat associations, when habitat variables are measured at the counting points. Monthly observations were taken for the behavior study. Essential ethological studies, including its daily schedule of activities, feeding and drinking behaviors were observed by the scan sampling method from dawn to dusk. The maximum numbers of birds will be recorded by using a binocular (Nikon, 10x50) and they were photographed by using Nikon camera. The birds available in these zones were counted. The flock size was determined according to their assemblage in the air or at the ground. A total of 672 observations were made at study area (288 observations at three sites; 384 observations at two sites) during two years period. The population of Streptopelia decaocto was performed at every weekly field visit and counted directly. Thus, eight counts of population generated every month. Average of the eight counts calculated as monthly average population. This monthly average population is tabulated during the study period.

\subsection{Determination of observation sites: -}

Taking into consideration of the above facts, the study area was divided into two categories - NonHuman Habitat $(\mathrm{NHH})$ and the Human Habitat $(\mathrm{HH})$, both having a total of five observation sites marked therein. The Non-Human Habitat included two observation sites, (I) Dasa Ki Dhani and (II) Nani Field whereas the Human Habitat included three observation sites, (III) Kurli Field, (IV) Gokulpura Field and (V) Kissan colony. The study site I, II, III and IV are situated 3-4 km. far from the Sikar town. Site I and II are the open fields and site III and IV are irrigated area where site V is urban area.At every field visit, selection of trees for various activities by collared dove was recorded and monthly average was tabulated. There are three types of trees are present in the study area i.e. large trees, Medium trees and Small trees. In each group five most commonly found tree species in the area were identified and selected for study of spatial arrangement of $S$. decaocto. Large trees included Aadu (Ailanthus excelsa), Khejri (Prosopis cineraria), Shisham (Dalbergia sissoo), Neem (Azadiracta indica) and Kikar (Acacia nilotica), which were having big canopy in general, whereas Medium trees were Beel (Aegle marmelos), Kikar (Acacia nilotica), Neem (Azadiracta indica), Amla (Emblica officinalis) and Shisham (Dalbergia sissoo) having comparatively intermediate sized canopy. Small trees included Kikar (Acacia nilotica), Rohida (Tecomella undulata), Khejri (Prosopis cineraria), Karonda (Carissa carandas) and Kheri (Acacia jacquemontii) having small canopy. Most of the activities on small trees were observed in the rainy season and least activities in the winters. Less spatial arrangement has been observed during winter season November to February. It is due to the environmental factors along with socio-economic importance of tree, that time people used such tree foliage as a fodder for cattle's and wood for fuel. So high disturbance, least foliage and low temperature lower down their spatial arrangement population in study area. Bird's population rises during June to September i.e. after post monsoon period. That time birds start breeding and nesting behavior.

\section{RESULT AND DISCUSSIONS" \\ 3.1 Roosting Tree Preference by Collared Dove (Streptopelia decaocto)}

Collared Dove $(S$. decaocto) preferred the medium and large trees for perching and roosting. $S$. decaocto was seen to perch at the middle, lateral middle and upper canopy and was always observed to roost in middle and lateral branches. The roosting of Collared Dove have been observed as the community roosting consisting of two species (House sparrow, Red-vented Bulbul) or two species on a single tree. Madhav Gadgil and Salim Ali (1975) have described the Collared Dove (S. decaocto), Crows, Hedge Sparrow and Owls roosting in the mixed community or sometimes have a single species [1]. Sengupta (1973), Davis (1974) has described that the selection of roosting site for the safety point of view against the predators [2], [3]. Spatial arrangement of Collared Dove ( $S$. decaocto) was studies and observations were tabulated in "Table" 1 . It is observed that $S$. decaocto preferred only Prosopis cineraria, Dalbergia sissoo and Azadiracta indica out of these five large trees, where as Ailanthus excelsa and Acacia nilotica were not selected for its activities. Most number of birds found on Prosopis cineraria in rainy season and the least number was on Azadiracta indica in summers. In medium trees the bird inhabited only three (Aegle marmelos, Azadiracta indica and Emblica officinalis) out of five studied trees. Among three of them, Aegle marmelos was the most preferred tree, whereas Emblica officinalis was least preferred. Activities on these trees were found to be of similar intensity round the year. The bird does not prefer small trees, as four of five trees were not selected as site for its activities. 
Tecomella undulata was the only selected tree as activity site by the bird. Activities on these trees were found to occur round the year.

\subsection{Month wise population of Collared Dove (Streptopelia decaocto)}

The month wise population distribution of S. decaocto ("Table" 1 \& "Fig." 1) observed on the selected trees in the study area. The maximum population was recorded in the months of May (16.25) followed by March (16.24) and April (15.87). The minimum population was recorded in the months January (10.75) followed by December (11.11) and November (11.48). The main reason of this decline is scarcity of food and lack of good shelter conditions or damage to the habitat by humans.

\subsection{Basking Behavior}

When a bird exposes itself to the sun to get its warmth, this activity is called Baking Behavior. It is the most common behavior performed by almost all the bird species. Result of basking behavior of $S$. decaocto is shown in "Table" 2. On analyzing "Table" 2 , it is observed that $S$. decaocto performs basking behavior only in the winter season. Basking observed in middle of the day from 11:00 AM to 2:00 PM. No birds were found basking in early morning and afternoon hours. Maximum basking activity was observed in late morning 11:00 AM to 12:00 PM (66.66\%) and minimum activity was observed in noon 12:00 PM to 1:00 PM (33.33\%). No basking activity observed in rainy and summer season. Graphical representation of the results is shown in "Fig." 2.

\subsection{Preening Behavior}

When a bird straighten and clean its feather with its beak, it called Preening Behavior. It is the most common behavior performed by almost all the bird species. Result of preening behavior of $S$. decaocto is shown in "Table" 3 . On analyzing "Table" 3 , it is observed that $S$. decaocto performs preening behavior preferably in the summer season. Most number of birds performed preening activity in summer season between 10:00 AM to 11:00 AM. But in the time of 5:00 AM to 6:00 AM in the morning, and 1:00 PM to 2:00 PM in noon no bird found preening. It is found that in summer and rainy season no preening activity was performed between 12:00 PM to 4:00 PM. In summer season minimum preening activity (12.50\%) was observed in evening 5:00 PM to 6:00 PM and maximum preening activity was (50\%). Preening activity was performed almost throughout the day in winter (16.33\% to $50 \%)$ and rainy season (20\% to $40 \%)$, respectively. Graphical representation of the results is shown in "Fig." 3.

\subsection{Foraging Behavior}

Foraging behavior is an activity of searching for food by bird in its habitat. Birds adopt many strategies for this purpose. It is the essential behavior performed by almost all the bird species for their survival. Result of foraging behavior of $S$. decaocto is shown in "Table" 4 . On analyzing "Table" 4, it is observed that $S$. decaocto performs foraging behavior throughout the day. Foraging activities in summer season started early morning 5:00 AM and intensified till late morning, but after 12:00 PM forging slowed down. Foraging activities intensifies again in afternoon hour and continued till dusk. In winter season foraging activities found to be most intense in noon hours in all seasons. In rainy and winter season foraging activity started after 6:00 AM which was most intense $(80 \% \& 83.33 \%)$ during late morning and least intense $(10 \%$ \& $25 \%)$ during noon and afternoon. In summer season maximum activity $(87.50 \%)$ was observed 10:00 AM to 11:00 AM and minimum activity was (10\%) in noon 2:00 PM to 3:00 PM. Graphical representation of the results is shown in "Fig."4.

\subsection{Feeding Behavior}

Foraging behavior is an activity of taking food or eating something by bird for nourishment. It is the essential behavior performed by all the bird species for their survival. Result of feeding behavior of $S$. decaocto is shown in "Table" 5. On analyzing "Table" 5, it is observed that $S$. decaocto performs feeding behavior throughout the day. Feeding activities in summer season started with dawn and intensified till late morning, but after 12:00 PM feeding slowed down. In rainy and winter season feeding activities started 6:00 AM. Feeding activities intensifies again in afternoon hour and continued till dusk in all three seasons. Maximum feeding activities was observed in all seasons in late morning 10:00 AM to 12:00 PM. In winter season feeding activities found to be most intense in noon hours. Highest peak of feeding activities were observed in $(75 \%, 80 \%$ \& $66.66 \%)$ and lowest was recorded $(10 \%, 20 \%$ \& $20 \%)$ in summer, rainy and winter season respectively. Graphical representation of the results is shown in "Fig."5.

\subsection{Drinking Behavior}

Water is the essential liquid for life; therefore drinking is an essential activity in birds' daily schedule. $S$ decaocto drinks by sucking and don't need to put the head back to swallow. Result of drinking behavior of $S$. decaocto is shown in "Table" 6. On analyzing "Table" 6, it is observed that S. decaocto performs drinking 
behavior almost unanimously throughout the year. It was observed that the bird drank twice in a day. In morning time drinking activity noted between 7:00 AM to 11:00 AM and in afternoon hours between 3:00 PM to 6:00 PM. Because summer season is very hot in the study area, some birds found drinking water in noon hours (11:00 AM to 12:00 PM) in summer season. The graphical representation of the results is shown in "Fig."6.

\subsection{Noon-Afternoon Rest}

Resting is an essential activity conducted by birds to refresh and recharge their body. Results of resting behavior of $S$. decaocto are shown in "Table" 7. On analyzing "Table" 7, it is observed that $S$. decaocto performs resting behavior almost unanimously throughout the year. It was observed that the bird rested only in the latter half of the day. Resting activities generally started after 12:00 PM in the noon. In summer season, when atmospheric temperature was high resting started a little earlier i.e. 11:00 AM to 12:00 PM in the late morning. In summer and winter season no, resting activity was observed after 6:00 PM, but in rainy season resting continued till 7:00 PM. In rainy season, no bird found resting in early afternoon hours (3:00 PM to 4:00 PM). High and low peak of resting behavior was seen $(62.50 \%, 70 \% \& 75 \%)$ and $(12.50 \%, 20 \% \& 20 \%)$ in summer, rainy and winter season respectively. The graphical representation of the results is shown in "Fig."7.

\subsection{Chasing Behavior}

Chasing is an important activity conducted by birds. Chasing may a part of intra-specific relationship or inter-specific relationship. The purpose of chasing could be a social activity, completion for food, breeding, revenge or security. Results of chasing behavior of $S$. decaocto are shown in "Table" 8 . On analyzing "Table" 8 , it is observed that $S$. decaocto performs chasing behavior almost similarly throughout the year. Chasing activities generally started after 8:00 AM in the morning. In winter season, when atmospheric temperature was low chasing started a little latter after 9:00 AM, and ended till 6:00 PM. In rainy season, no bird found chasing in noon hours (12:00 PM to1:00 PM). The most intense chasing behavior $(37.50 \%, 50 \% \& 40 \%)$ and least intense $(10 \%, 20 \% \& 20 \%)$ were visible in summer, rainy and winter season respectively. The graphical representation of the results is shown in "Fig." 8.

\subsection{Fighting Behavior}

Fighting is an important activity conducted by birds. Fighting may a part of intra-specific relationship or inter-specific relationship. The purpose of fighting could be completion for food, breeding, revenge or security. Results of fighting behavior of $S$. decaocto are shown in "Table" 9. On analyzing "Table" 9, it is observed that $S$. decaocto performs fighting behavior almost similarly throughout the year. Fighting activities generally started after 8:00 AM in summer and rainy season. In winter season, when atmospheric temperature was low fighting started a little latter after 9:00 AM, and ended till 6:00 PM. In rainy season, no bird found fighting in noon hours (12:00 PM to1:00 PM). High peak (40\%, 40\% \& 50\%) and low peak (10\%, 20\% \& 25\%) of fighting activities were observed in summer, rainy and winter season respectively. The graphical representation of the results is shown in "Fig."9.

\subsection{Vocalization Behavior}

Birds produce many types of sounds in their vocalization behavior. The sound can be a bird song, a simple call, a breeding call, or a warning call. Results of vocalization behavior of $S$. decaocto are shown in "Table" 10 . On analyzing "Table" 10 , it is observed that $S$. decaocto performs vocalization behavior almost unanimously throughout the year. Vocalization activities generally started dawn $(87.50 \%, 80 \% \& 83.33 \%)$ in the morning, and continued till dusk $(62.50 \%, 50 \% \& 37.50 \%)$ in all three seasons. The graphical representation of the results is shown in "Fig." 10.

\section{Conclusion}

Streptopelia decaocto preferred as nesting and roosting plant species like as Khejri (Prosopis cineraria), Kikar (Acacia nilotica) and Neem (Azardirecta indica). The maximum population was recorded during the rainy season i.e. the months of July, August and September. Maximum activities performed by the collared dove in the early morning to late morning (5.00 AM to $11.00 \mathrm{AM})$ and less activities performed in afternoon to evening (3.30 PM to 7.00 PM).

\section{ACKNOWLEDGEMENT}

This paper is based on my field observations. This study would not have been possible without the financial cooperation of University Grant Commission, Bhopal. I am grateful to UGC, Bhopal for their financial assistance in the form of Minor Research Project. 


\section{REFERENCES}

[1] Gadgil, M. and Ali, S. (1975): “Communal roosting habits of Indian birds". JBNHS.72 (3): 716-727.

[2] Sengupta, S. (1973): Significance of communal roosting in the common myna (A. tristis Linn.) JBNHS Vol. 70. 204-206.

[3] Davis, T. A. (1974): Selection of nesting trees and the frequency of nest visits by baya weaverbird; JBNHS 71. 356-366.

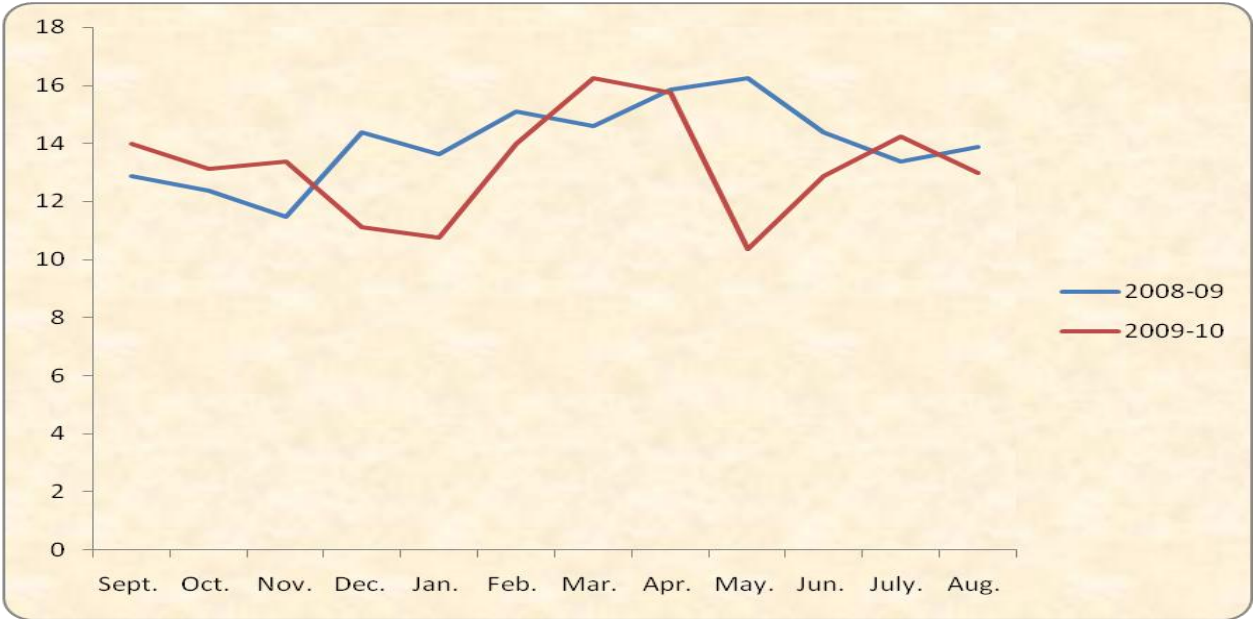

Figure 1 showing the month wise population distribution of $S$. decaocto.

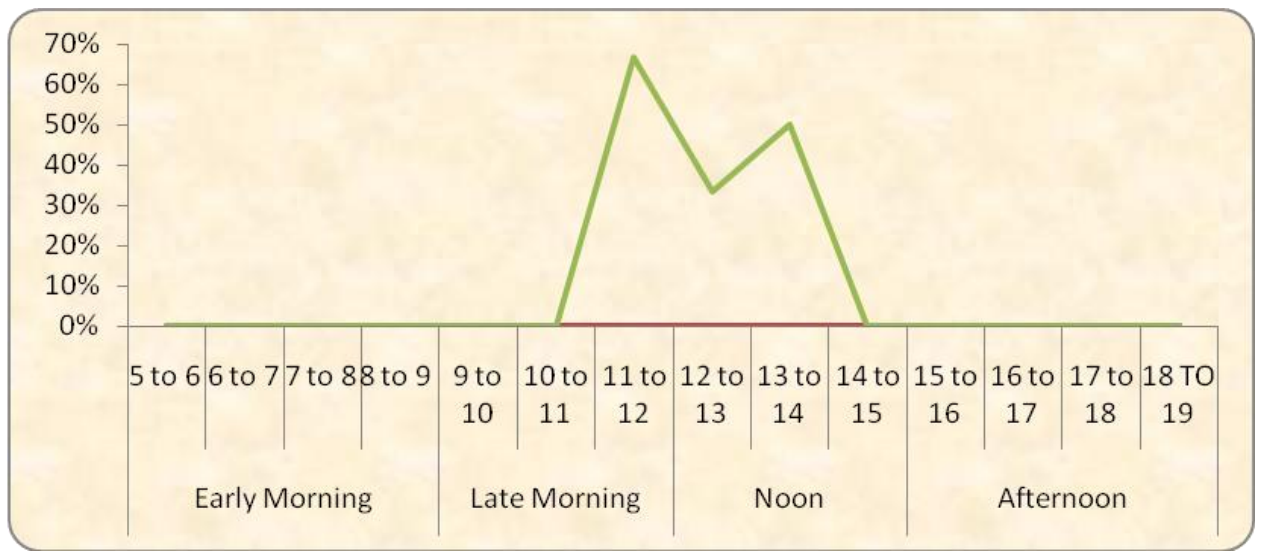

Figure 2 S. decaocto: -Showing Basking behavior during winter season.

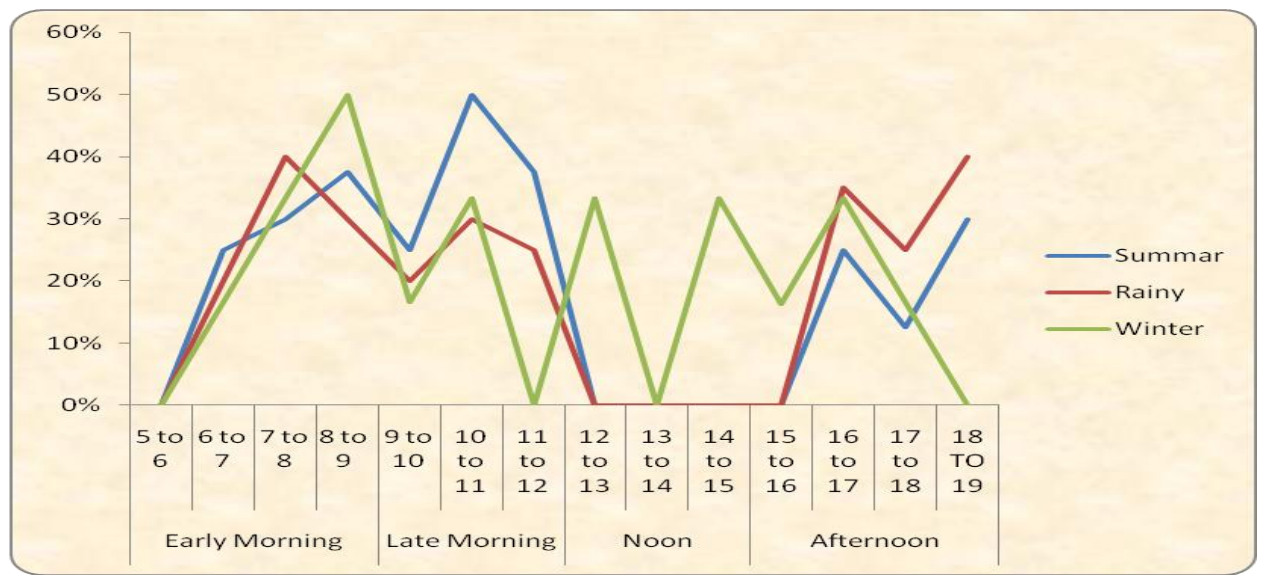

Figure 3 S. decaocto: -Showing seasonal trend of preening behavior. 


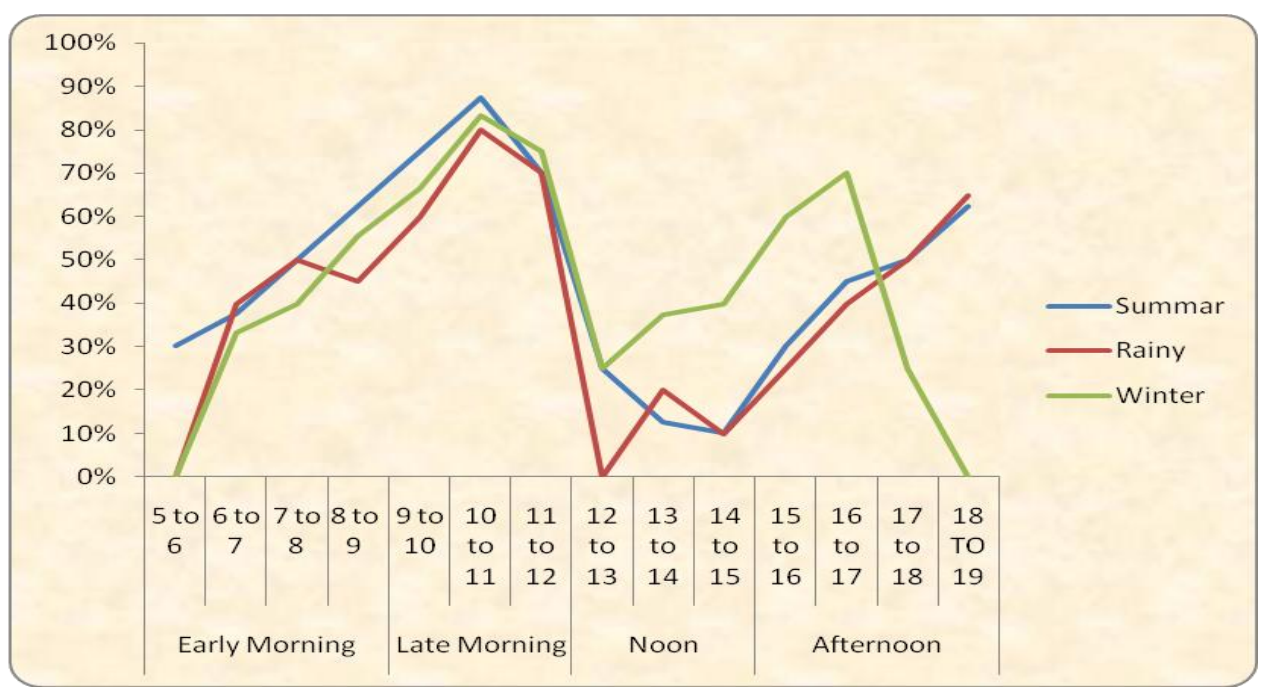

Figure 4 S. decaocto: -Showing seasonal trend of foraging behavior.

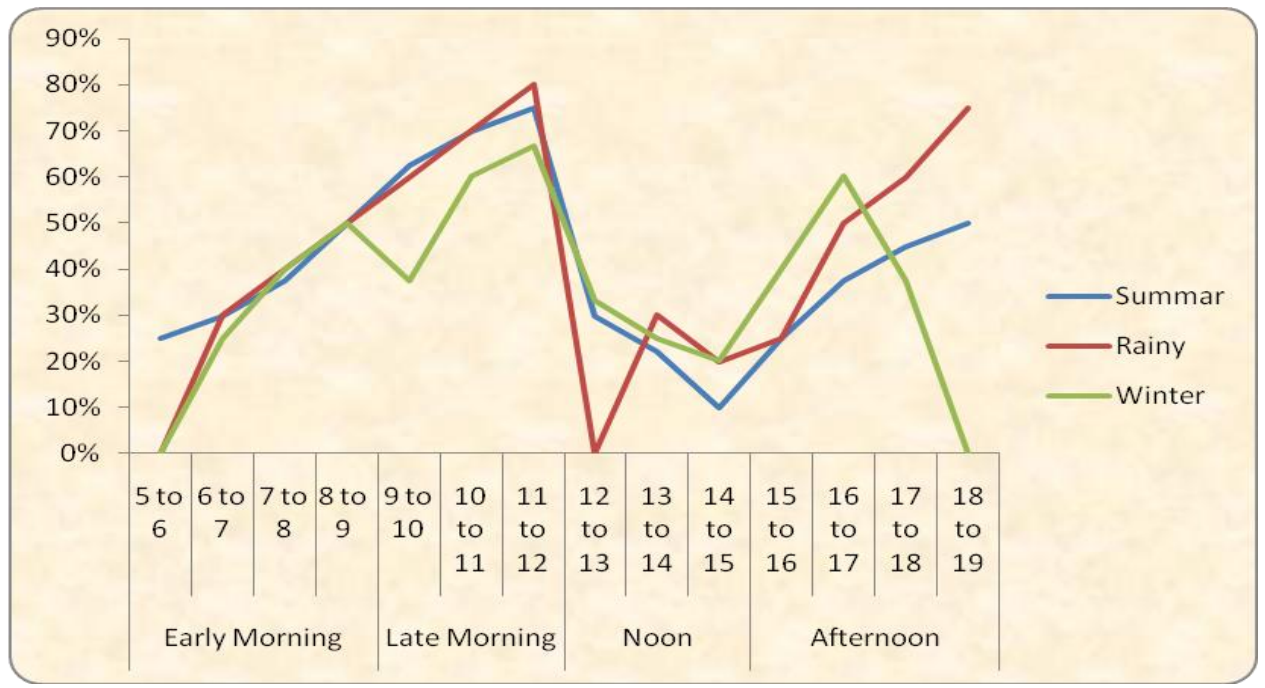

Figure 5 S. decaocto: -Showing seasonal trend of feeding behavior.

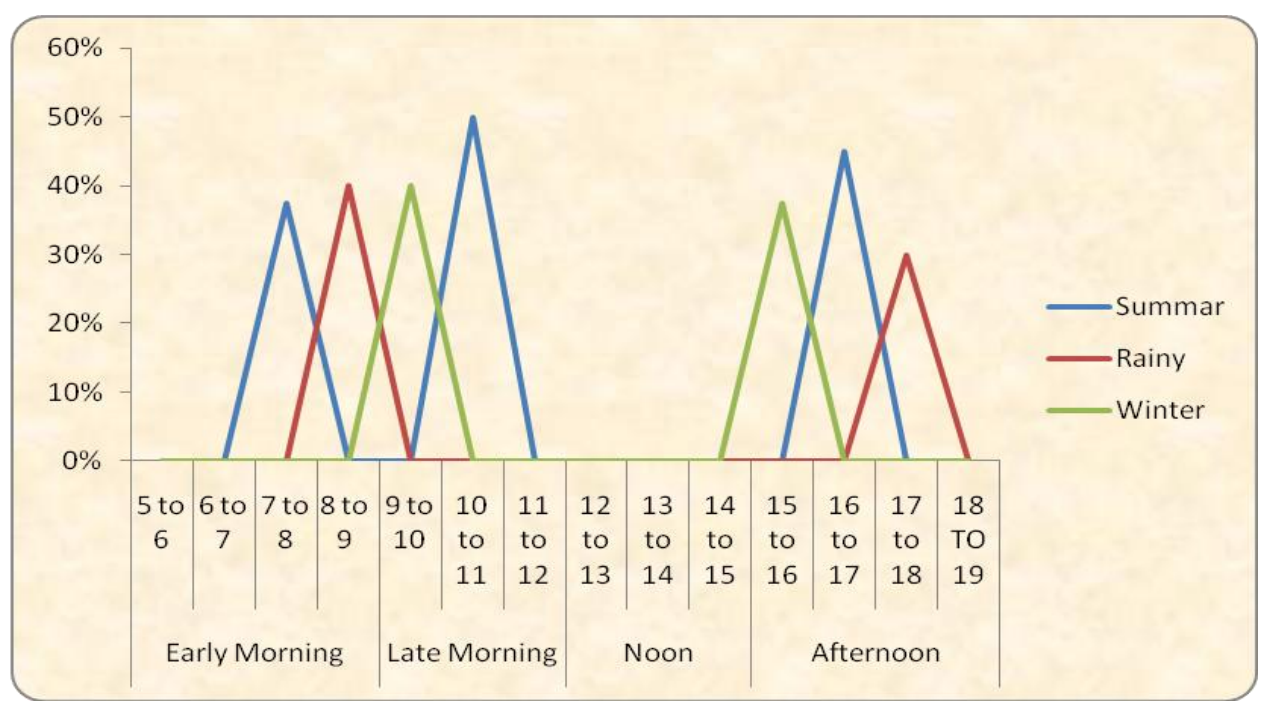

Figure 6 S. decaocto: -Showing seasonal trend of drinking behavior. 


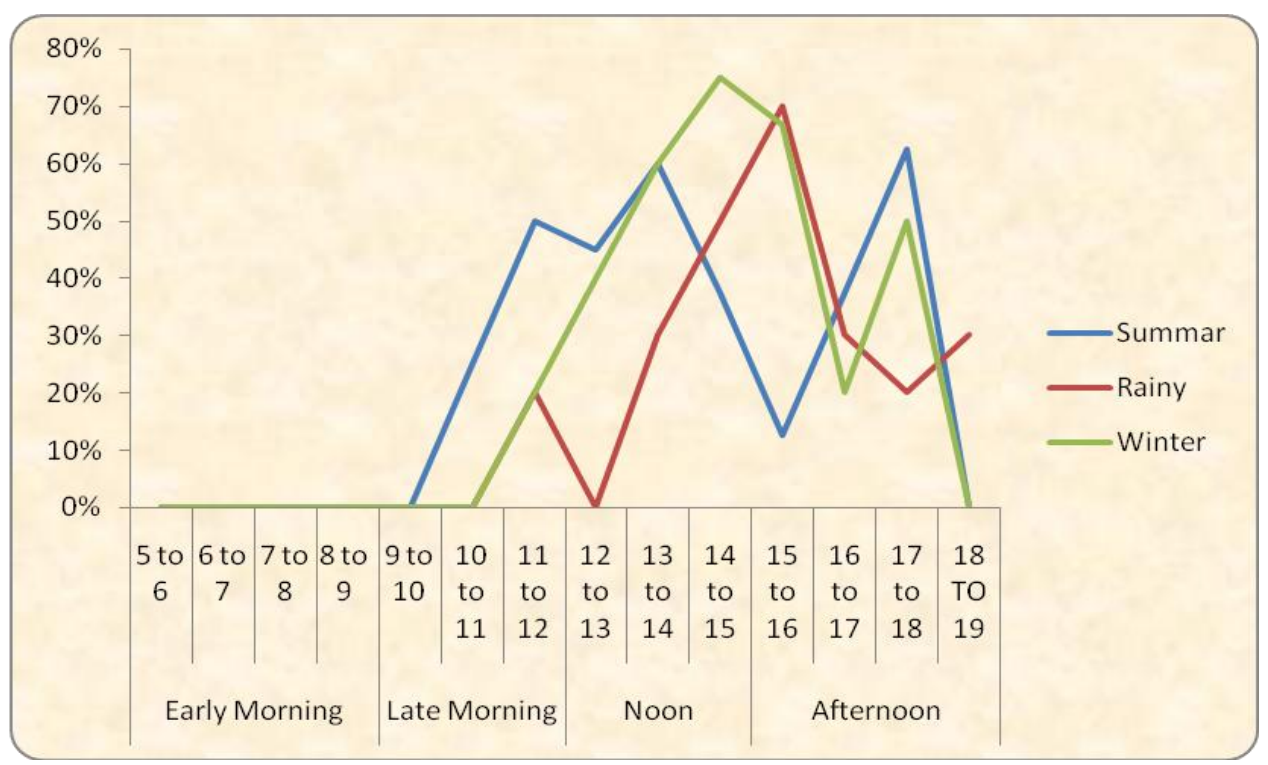

Figure 7 S. decaocto: -Showing seasonal trend of resting behavior.

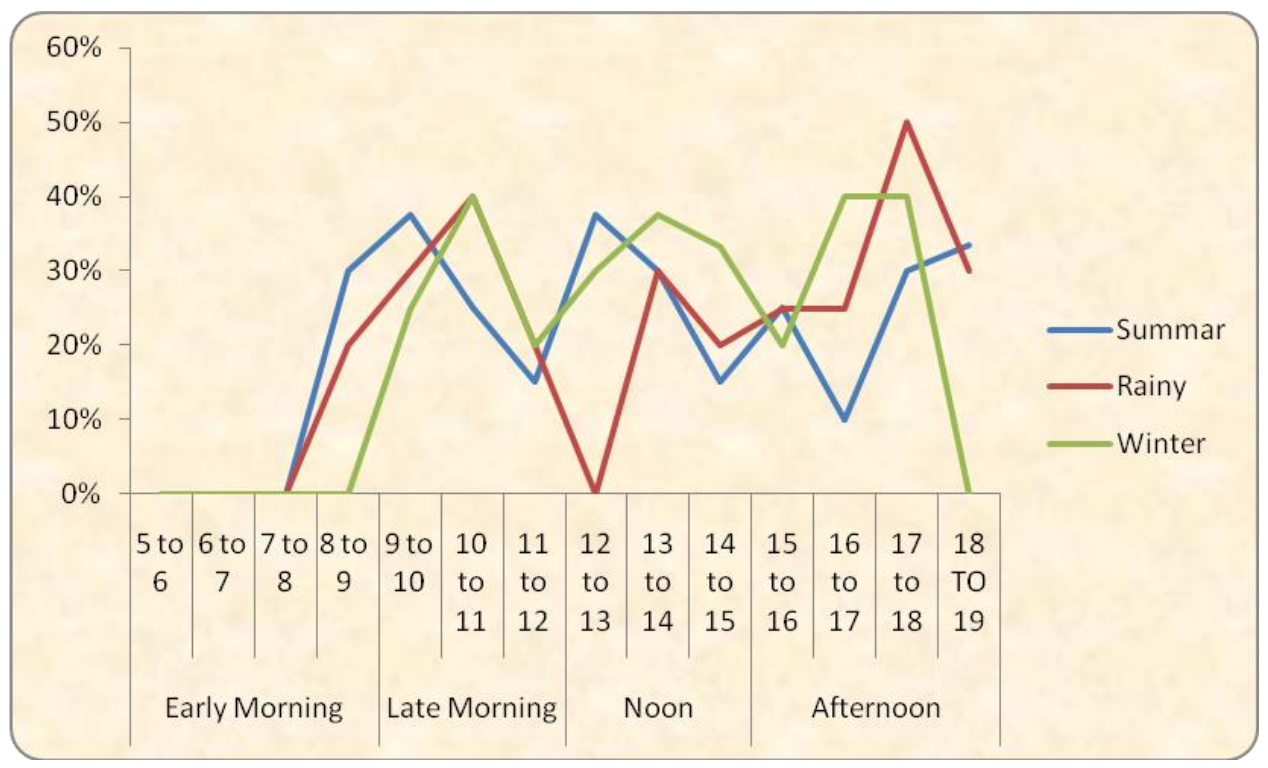

Figure 8 S. decaocto: -Showing seasonal trend of chasing behavior. 


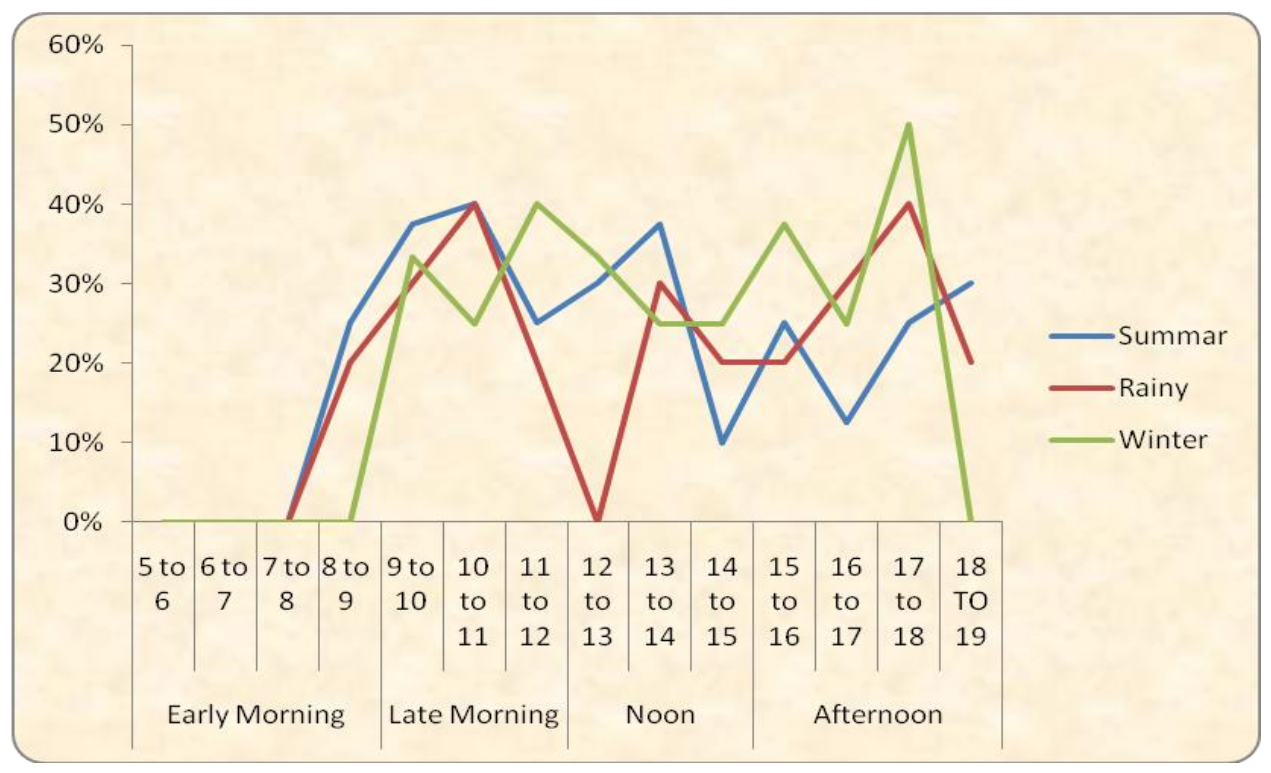

Figure 9 S. decaocto: -Showing seasonal trend of fighting behavior.

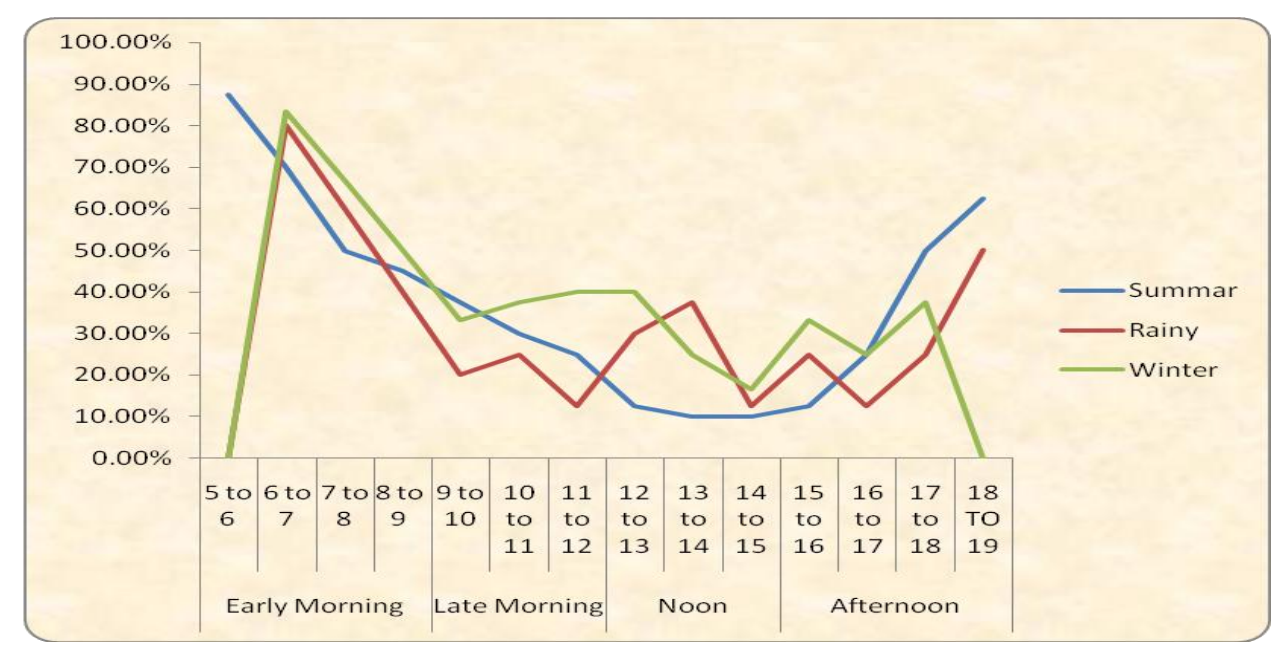

Figure $10 \mathrm{~S}$. decaocto: -Showing seasonal trend of vocalization behavior.

Table 1:- Habitat selection and Spatial Arrangement of Collared Dove (Streptopelia decaocto)

\begin{tabular}{|c|c|c|c|c|c|c|c|c|c|c|c|c|c|c|c|c|}
\hline \multirow[b]{2}{*}{$\begin{array}{c}\text { Mont } \\
\text { hs }\end{array}$} & \multicolumn{5}{|c|}{ Large Tree } & \multicolumn{5}{|c|}{ Medium Tree } & \multicolumn{5}{|c|}{ Small Tree } & \multirow[b]{2}{*}{$\begin{array}{c}\text { Tota } \\
\text { I }\end{array}$} \\
\hline & $\begin{array}{l}\text { Aa } \\
\text { du }\end{array}$ & $\begin{array}{c}\text { Khej } \\
\text { ri }\end{array}$ & $\begin{array}{c}\begin{array}{c}\text { Shish } \\
\text { am }\end{array} \\
\end{array}$ & $\begin{array}{c}\text { Nee } \\
\text { m }\end{array}$ & $\begin{array}{c}\text { Kik } \\
\text { ar }\end{array}$ & $\begin{array}{c}\text { Bee } \\
1\end{array}$ & $\begin{array}{c}\text { Kik } \\
\text { ar }\end{array}$ & $\begin{array}{c}\text { Nee } \\
\text { m }\end{array}$ & $\begin{array}{c}\text { Am } \\
\text { la }\end{array}$ & $\begin{array}{c}\begin{array}{c}\text { Shish } \\
\text { am }\end{array} \\
\end{array}$ & $\begin{array}{c}\begin{array}{c}\text { Kik } \\
\text { ar }\end{array} \\
\end{array}$ & $\begin{array}{c}\text { Rohi } \\
\text { da }\end{array}$ & $\begin{array}{c}\text { Khej } \\
\text { ri }\end{array}$ & $\begin{array}{c}\text { Karon } \\
\text { da }\end{array}$ & $\begin{array}{c}\text { Khe } \\
\text { ri }\end{array}$ & \\
\hline $\begin{array}{l}\text { July. } \\
10\end{array}$ & - & 7.62 & 1.75 & - & - & $\begin{array}{c}1.8 \\
7\end{array}$ & - & 0.75 & - & - & - & 0.87 & - & - & - & $\begin{array}{c}12.8 \\
7\end{array}$ \\
\hline $\begin{array}{l}\text { Aug. } \\
10\end{array}$ & - & 4.75 & 0.87 & 1.00 & - & $\begin{array}{c}2.0 \\
0\end{array}$ & - & 1.00 & $\begin{array}{c}0.8 \\
7\end{array}$ & - & - & 1.87 & - & - & - & $\begin{array}{c}12.3 \\
7\end{array}$ \\
\hline $\begin{array}{l}\text { Sep.1 } \\
0\end{array}$ & - & 5.87 & 1.87 & - & - & $\begin{array}{c}0.8 \\
7\end{array}$ & - & - & $\begin{array}{c}1.0 \\
0\end{array}$ & - & - & 1.87 & - & - & - & $\begin{array}{c}11.4 \\
8\end{array}$ \\
\hline $\begin{array}{l}\text { Oct.1 } \\
0 \\
\end{array}$ & - & 6.87 & 1.75 & 1.87 & - & $\begin{array}{c}1.0 \\
0 \\
\end{array}$ & - & 0.87 & - & - & - & 2.00 & - & - & - & $\begin{array}{c}14.3 \\
7 \\
\end{array}$ \\
\hline $\begin{array}{l}\text { Nov. } \\
10\end{array}$ & - & 5.87 & 2.00 & 1.00 & - & $\begin{array}{c}0.8 \\
7\end{array}$ & - & 1.00 & $\begin{array}{c}0.8 \\
7\end{array}$ & - & - & 2.00 & - & - & - & $\begin{array}{c}13.6 \\
2\end{array}$ \\
\hline $\begin{array}{l}\text { Dec. } 1 \\
0\end{array}$ & - & 7.75 & 1.75 & - & - & $\begin{array}{c}1.7 \\
5\end{array}$ & - & 0.87 & $\begin{array}{c}1.0 \\
0\end{array}$ & - & - & 2.00 & - & - & - & $\begin{array}{c}15.1 \\
2\end{array}$ \\
\hline $\begin{array}{l}\text { Jan.1 } \\
1\end{array}$ & - & 7.00 & 1.87 & - & - & $\begin{array}{c}2.0 \\
0\end{array}$ & - & 1.87 & $\begin{array}{c}0.8 \\
7\end{array}$ & - & - & 1.00 & - & - & - & $\begin{array}{c}14.6 \\
1\end{array}$ \\
\hline $\begin{array}{l}\text { Feb. } 1 \\
1\end{array}$ & - & 8.50 & 1.25 & 1.50 & - & $\begin{array}{c}1.0 \\
0\end{array}$ & - & 0.87 & $\begin{array}{c}0.8 \\
7\end{array}$ & - & - & 1.87 & - & - & - & $\begin{array}{c}15.8 \\
7\end{array}$ \\
\hline $\begin{array}{l}\text { Mar.1 } \\
1\end{array}$ & - & 8.62 & 1.87 & - & - & $\begin{array}{c}2.0 \\
0\end{array}$ & - & 1.75 & - & - & - & 2.00 & - & - & - & $\begin{array}{c}16.2 \\
5\end{array}$ \\
\hline Apr.1 & - & 6.75 & 1.87 & 0.87 & - & 1.0 & - & 1.00 & 1.0 & - & - & 1.87 & - & - & - & 14.3 \\
\hline
\end{tabular}


Distribution And Daily Activity Of Collared...

\begin{tabular}{|c|c|c|c|c|c|c|c|c|c|c|c|c|c|c|c|c|}
\hline 1 & & & & & & 0 & & & 0 & & & & & & & 7 \\
\hline $\begin{array}{l}\text { May. } \\
11\end{array}$ & - & 7.50 & 1.25 & 1.37 & - & $\begin{array}{c}1.1 \\
2\end{array}$ & - & 1.12 & - & - & - & 2.00 & - & - & - & $\begin{array}{c}14.3 \\
7\end{array}$ \\
\hline $\begin{array}{l}\text { Jun.1 } \\
1 \\
\end{array}$ & - & 7.62 & 1.87 & 1.00 & - & $\begin{array}{c}0.7 \\
5\end{array}$ & - & 0.87 & $\begin{array}{c}1.0 \\
0 \\
\end{array}$ & - & - & 1.75 & - & - & - & $\begin{array}{c}14.8 \\
7 \\
\end{array}$ \\
\hline Total & & $\begin{array}{c}84.7 \\
2 \\
\end{array}$ & 19.97 & 8.61 & & $\begin{array}{l}16 . \\
23\end{array}$ & & $\begin{array}{c}11.9 \\
7\end{array}$ & $\begin{array}{c}7.4 \\
8\end{array}$ & & & 21.10 & & & & $\begin{array}{c}170 . \\
08\end{array}$ \\
\hline $\begin{array}{l}\text { July. } \\
11\end{array}$ & - & 8.00 & 2.00 & - & - & $\begin{array}{c}2.0 \\
0\end{array}$ & - & - & - & - & - & 2.00 & - & - & - & $\begin{array}{c}14.0 \\
0\end{array}$ \\
\hline $\begin{array}{l}\text { Aug. } \\
11\end{array}$ & - & 5.75 & 1.75 & 0.87 & - & $\begin{array}{c}1.8 \\
7\end{array}$ & - & 1.00 & $\begin{array}{c}0.8 \\
7 \\
\end{array}$ & - & - & 1.00 & - & - & - & $\begin{array}{c}13.1 \\
1\end{array}$ \\
\hline $\begin{array}{l}\text { Sep. } 1 \\
1\end{array}$ & - & 7.62 & 1.00 & - & - & $\begin{array}{c}0.8 \\
7 \\
\end{array}$ & - & 1.00 & $\begin{array}{c}0.8 \\
7 \\
\end{array}$ & - & - & 2.00 & - & - & - & $\begin{array}{c}13.3 \\
6 \\
\end{array}$ \\
\hline $\begin{array}{l}\text { Oct.1 } \\
1\end{array}$ & - & 5.87 & 1.00 & 1.62 & - & $\begin{array}{c}0.8 \\
7 \\
\end{array}$ & - & - & - & - & - & 1.75 & - & - & - & $\begin{array}{c}11.1 \\
1 \\
\end{array}$ \\
\hline $\begin{array}{l}\text { Nov. } \\
11 \\
\end{array}$ & - & 5.75 & 2.00 & 1.00 & - & $\begin{array}{c}1.0 \\
0 \\
\end{array}$ & - & - & $\begin{array}{c}1.0 \\
0 \\
\end{array}$ & - & - & - & - & - & - & $\begin{array}{c}10.7 \\
5\end{array}$ \\
\hline $\begin{array}{l}\text { Dec. } 1 \\
1\end{array}$ & - & 8.62 & 1.87 & - & - & $\begin{array}{c}1.7 \\
5\end{array}$ & - & - & - & - & - & 1.75 & - & - & - & $\begin{array}{c}13.9 \\
9\end{array}$ \\
\hline $\begin{array}{l}\text { Jan.1 } \\
2 \\
\end{array}$ & - & 7.75 & 1.87 & - & - & $\begin{array}{c}1.7 \\
5\end{array}$ & - & 1.87 & $\begin{array}{c}1.0 \\
0 \\
\end{array}$ & - & - & 2.00 & - & - & - & $\begin{array}{c}16.2 \\
4\end{array}$ \\
\hline $\begin{array}{l}\text { Feb.1 } \\
2\end{array}$ & - & 9.25 & 1.75 & 0.87 & - & $\begin{array}{c}0.8 \\
7\end{array}$ & - & - & $\begin{array}{c}1.0 \\
0 \\
\end{array}$ & - & - & 2.00 & - & - & - & $\begin{array}{c}15.7 \\
4 \\
\end{array}$ \\
\hline $\begin{array}{l}\text { Mar.1 } \\
2\end{array}$ & - & 4.75 & 1.00 & - & - & $\begin{array}{c}1.7 \\
5\end{array}$ & - & - & $\begin{array}{c}1.0 \\
0 \\
\end{array}$ & - & - & 1.87 & - & - & - & $\begin{array}{c}10.3 \\
7 \\
\end{array}$ \\
\hline $\begin{array}{l}\text { Apr. } 1 \\
2 \\
\end{array}$ & - & 5.87 & 2.00 & - & - & $\begin{array}{c}1.0 \\
0\end{array}$ & - & 2.00 & - & - & - & 2.00 & - & - & - & $\begin{array}{c}12.8 \\
7\end{array}$ \\
\hline $\begin{array}{l}\text { May. } \\
12\end{array}$ & - & 7.25 & 2.00 & 1.00 & - & $\begin{array}{c}1.0 \\
0\end{array}$ & - & 1.00 & - & - & - & 2.00 & - & - & - & $\begin{array}{c}14.2 \\
5\end{array}$ \\
\hline $\begin{array}{l}\text { Jun.1 } \\
2 \\
\end{array}$ & - & 5.00 & 2.00 & 1.00 & - & $\begin{array}{c}1.0 \\
0 \\
\end{array}$ & - & 2.00 & $\begin{array}{c}1.0 \\
0 \\
\end{array}$ & - & - & 2.00 & - & - & - & $\begin{array}{c}14.0 \\
0\end{array}$ \\
\hline Total & & $\begin{array}{c}81.4 \\
8\end{array}$ & 20.24 & 6.36 & & $\begin{array}{l}15 . \\
73\end{array}$ & & 8.87 & $\begin{array}{c}6.7 \\
4\end{array}$ & & & 20.37 & & & & $\begin{array}{c}159 . \\
79\end{array}$ \\
\hline
\end{tabular}

Table 2:- Streptopelia decaocto: Showing Basking Behavior during winter season.

\begin{tabular}{|c|c|c|c|c|c|c|c|c|c|c|c|c|c|c|}
\hline \multirow[b]{2}{*}{ Season } & \multicolumn{4}{|c|}{ Early Morning } & \multicolumn{3}{|c|}{ Late Morning } & \multicolumn{3}{|c|}{ Noon } & \multicolumn{4}{|c|}{ Afternoon } \\
\hline & $\begin{array}{r}5 \\
\text { to } \\
6 \\
\end{array}$ & $\begin{array}{c}6 \\
\text { to } \\
7 \\
\end{array}$ & $\begin{array}{c}7 \\
\text { to } \\
8 \\
\end{array}$ & $\begin{array}{c}8 \\
\text { to } \\
9 \\
\end{array}$ & $\begin{array}{c}9 \text { to } \\
10\end{array}$ & $\begin{array}{c}10 \text { to } \\
11\end{array}$ & $\begin{array}{c}11 \text { to } \\
12\end{array}$ & 12 to 1 & $\begin{array}{c}1 \text { to } \\
2\end{array}$ & $\begin{array}{c}2 \\
\text { to } \\
3 \\
\end{array}$ & $\begin{array}{c}3 \\
\text { to } \\
4 \\
\end{array}$ & $\begin{array}{c}4 \text { to } \\
5\end{array}$ & $\begin{array}{c}5 \text { to } \\
6\end{array}$ & 6 to 7 \\
\hline Summer & - & - & - & - & - & - & - & - & - & - & - & - & - & - \\
\hline Rainy & - & - & - & - & - & - & - & - & - & - & - & - & - & - \\
\hline Winter & - & - & - & - & - & - & $66.66 \%$ & $33.33 \%$ & $50 \%$ & - & - & - & - & - \\
\hline
\end{tabular}

Table 3:- Streptopelia decaocto: Showing seasonal trend of preening behavior.

\begin{tabular}{|c|c|c|c|c|c|c|c|c|c|c|c|c|c|c|}
\hline \multirow[b]{2}{*}{$\begin{array}{c}\text { Seaso } \\
\mathbf{n}\end{array}$} & \multicolumn{4}{|c|}{ Early Morning } & \multicolumn{3}{|c|}{ Late Morning } & \multicolumn{3}{|c|}{ Noon } & \multicolumn{4}{|c|}{ Afternoon } \\
\hline & $\begin{array}{l}5 \\
\mathrm{t} \\
\mathrm{o} \\
6 \\
\end{array}$ & $\begin{array}{c}6 \text { to } \\
7 \\
\end{array}$ & $\begin{array}{c}7 \text { to } \\
8 \\
\end{array}$ & $\begin{array}{c}8 \text { to } \\
9 \\
\end{array}$ & $\begin{array}{c}9 \text { to } \\
10 \\
\end{array}$ & $\begin{array}{c}10 \text { to } \\
11 \\
\end{array}$ & $\begin{array}{c}11 \text { to } \\
12 \\
\end{array}$ & $\begin{array}{c}12 \text { to } \\
1 \\
\end{array}$ & $\begin{array}{l}1 \\
\mathbf{t} \\
\mathbf{0} \\
\mathbf{2}\end{array}$ & $\begin{array}{c}2 \text { to } \\
3 \\
\end{array}$ & $\begin{array}{c}3 \text { to } \\
4 \\
\end{array}$ & $\begin{array}{c}4 \text { to } \\
5 \\
\end{array}$ & $\begin{array}{c}5 \text { to } \\
6 \\
\end{array}$ & $\begin{array}{c}6 \\
\text { to } \\
7 \\
\end{array}$ \\
\hline $\begin{array}{l}\text { Sum } \\
\text { mer }\end{array}$ & - & $25 \%$ & $30 \%$ & $\begin{array}{c}37.50 \\
\% \\
\end{array}$ & $25 \%$ & $50 \%$ & $\begin{array}{c}37.50 \\
\% \\
\end{array}$ & - & - & - & - & $25 \%$ & $\begin{array}{c}12.50 \\
\%\end{array}$ & $\begin{array}{l}30 \\
\% \\
\end{array}$ \\
\hline Rainy & - & $20 \%$ & $40 \%$ & $30 \%$ & $20 \%$ & $30 \%$ & $25 \%$ & - & - & - & - & $35 \%$ & $25 \%$ & $\begin{array}{l}40 \\
\%\end{array}$ \\
\hline $\begin{array}{l}\text { Winte } \\
\mathrm{r}\end{array}$ & - & $\begin{array}{c}16.66 \\
\%\end{array}$ & $\begin{array}{c}33.33 \\
\%\end{array}$ & $50 \%$ & $\begin{array}{c}16.66 \\
\%\end{array}$ & $\begin{array}{c}33.33 \\
\%\end{array}$ & & $\begin{array}{c}33.33 \\
\%\end{array}$ & _ & $\begin{array}{c}33.33 \\
\%\end{array}$ & $\begin{array}{c}16.33 \\
\%\end{array}$ & $\begin{array}{c}33.33 \\
\%\end{array}$ & $\begin{array}{c}16.66 \\
\%\end{array}$ & - \\
\hline
\end{tabular}

Table 4:- Streptopelia decaocto: Showing seasonal trend of foraging behavior. 
Distribution And Daily Activity Of Collared...

\begin{tabular}{|c|c|c|c|c|c|c|c|c|c|c|c|c|c|c|}
\hline \multirow[b]{2}{*}{$\begin{array}{c}\text { Seaso } \\
\mathbf{n}\end{array}$} & \multicolumn{4}{|c|}{ Early Morning } & \multicolumn{3}{|c|}{ Late Morning } & \multicolumn{3}{|c|}{ Noon } & \multicolumn{4}{|c|}{ Afternoon } \\
\hline & $\begin{array}{c}5 \\
\text { to } \\
6\end{array}$ & $\begin{array}{c}6 \text { to } \\
7\end{array}$ & $\begin{array}{c}7 \\
\text { to } \\
8\end{array}$ & $\begin{array}{c}8 \text { to } \\
9\end{array}$ & $\begin{array}{c}9 \text { to } \\
10\end{array}$ & $\begin{array}{c}10 \text { to } \\
11\end{array}$ & $\begin{array}{l}11 \\
\text { to } \\
12\end{array}$ & $\begin{array}{c}12 \\
\text { to } \\
1\end{array}$ & $\begin{array}{c}1 \text { to } \\
2\end{array}$ & $\begin{array}{c}2 \\
\text { to } \\
\mathbf{3}\end{array}$ & $\begin{array}{c}3 \\
\text { to } \\
4\end{array}$ & $\begin{array}{c}4 \\
\text { to } \\
5\end{array}$ & $\begin{array}{c}5 \\
\text { to } \\
6\end{array}$ & $\begin{array}{c}6 \text { to } \\
7\end{array}$ \\
\hline $\begin{array}{l}\text { Summ } \\
\text { er }\end{array}$ & $\begin{array}{l}30 \\
\%\end{array}$ & $\begin{array}{c}37.50 \\
\%\end{array}$ & $\begin{array}{l}50 \\
\%\end{array}$ & $\begin{array}{c}62.50 \\
\%\end{array}$ & $75 \%$ & $\begin{array}{c}87.50 \\
\%\end{array}$ & $\begin{array}{l}70 \\
\%\end{array}$ & $\begin{array}{l}25 \\
\%\end{array}$ & $\begin{array}{c}12.50 \\
\%\end{array}$ & $\begin{array}{l}10 \\
\%\end{array}$ & $\begin{array}{l}30 \\
\%\end{array}$ & $\begin{array}{l}45 \\
\%\end{array}$ & $\begin{array}{l}50 \\
\%\end{array}$ & $\begin{array}{c}62.50 \\
\%\end{array}$ \\
\hline Rainy & - & $40 \%$ & $\begin{array}{l}50 \\
\%\end{array}$ & $45 \%$ & $60 \%$ & $80 \%$ & $\begin{array}{l}70 \\
\% \\
\end{array}$ & - & $20 \%$ & $\begin{array}{l}10 \\
\%\end{array}$ & $\begin{array}{l}25 \\
\% \\
\end{array}$ & $\begin{array}{l}40 \\
\% \\
\end{array}$ & $\begin{array}{l}50 \\
\%\end{array}$ & $65 \%$ \\
\hline $\begin{array}{l}\text { Winte } \\
\mathrm{r}\end{array}$ & - & $\begin{array}{c}33.33 \\
\%\end{array}$ & $\begin{array}{l}40 \\
\%\end{array}$ & $\begin{array}{c}55.50 \\
\%\end{array}$ & $\begin{array}{c}66.66 \\
\%\end{array}$ & $\begin{array}{c}83.33 \\
\%\end{array}$ & $\begin{array}{l}75 \\
\%\end{array}$ & $\begin{array}{l}25 \\
\%\end{array}$ & $\begin{array}{c}37.50 \\
\%\end{array}$ & $\begin{array}{l}40 \\
\%\end{array}$ & $\begin{array}{l}60 \\
\%\end{array}$ & $\begin{array}{l}70 \\
\%\end{array}$ & $\begin{array}{l}25 \\
\%\end{array}$ & - \\
\hline
\end{tabular}

Table 5:- Streptopelia decaocto: Showing seasonal trend of feeding behavior.

\begin{tabular}{|c|c|c|c|c|c|c|c|c|c|c|c|c|c|c|}
\hline \multirow[b]{2}{*}{$\begin{array}{l}\text { Seaso } \\
n\end{array}$} & \multicolumn{4}{|c|}{ Early Morning } & \multicolumn{3}{|c|}{ Late Morning } & \multicolumn{3}{|c|}{ Noon } & \multicolumn{4}{|c|}{ Afternoon } \\
\hline & $\begin{array}{c}5 \\
\text { to } \\
6\end{array}$ & $\begin{array}{c}6 \\
\text { to } \\
7\end{array}$ & $\begin{array}{c}7 \text { to } \\
8\end{array}$ & $\begin{array}{c}8 \\
\text { to } \\
9\end{array}$ & $\begin{array}{c}9 \text { to } \\
10\end{array}$ & $\begin{array}{l}10 \\
\text { to } \\
11\end{array}$ & $\begin{array}{c}11 \text { to } \\
12\end{array}$ & $\begin{array}{c}12 \text { to } \\
1\end{array}$ & $\begin{array}{c}1 \text { to } \\
2\end{array}$ & $\begin{array}{c}2 \\
\text { to } \\
\mathbf{3}\end{array}$ & $\begin{array}{c}3 \\
\text { to } \\
4\end{array}$ & $\begin{array}{c}4 \text { to } \\
5\end{array}$ & $\begin{array}{c}5 \text { to } \\
6\end{array}$ & $\begin{array}{c}6 \\
\text { to } \\
7\end{array}$ \\
\hline $\begin{array}{l}\text { Sum } \\
\text { mer }\end{array}$ & $\begin{array}{l}25 \\
\% \\
\end{array}$ & $\begin{array}{l}30 \\
\%\end{array}$ & $\begin{array}{c}37.50 \\
\% \\
\end{array}$ & $\begin{array}{l}50 \\
\%\end{array}$ & $\begin{array}{c}62.50 \\
\% \\
\end{array}$ & $\begin{array}{l}70 \\
\% \\
\end{array}$ & $75 \%$ & $30 \%$ & $\begin{array}{c}22.25 \\
\%\end{array}$ & $\begin{array}{l}10 \\
\%\end{array}$ & $\begin{array}{l}25 \\
\% \\
\end{array}$ & $\begin{array}{c}37.50 \\
\%\end{array}$ & $45 \%$ & $\begin{array}{l}50 \\
\% \\
\end{array}$ \\
\hline Rainy & - & $\begin{array}{l}30 \\
\%\end{array}$ & $40 \%$ & $\begin{array}{l}50 \\
\%\end{array}$ & $60 \%$ & $\begin{array}{l}70 \\
\% \\
\end{array}$ & $80 \%$ & - & $30 \%$ & $\begin{array}{l}20 \\
\%\end{array}$ & $\begin{array}{l}25 \\
\%\end{array}$ & $50 \%$ & $60 \%$ & $\begin{array}{l}75 \\
\% \\
\end{array}$ \\
\hline $\begin{array}{l}\text { Winte } \\
\mathrm{r}\end{array}$ & - & $\begin{array}{l}25 \\
\%\end{array}$ & $40 \%$ & $\begin{array}{l}50 \\
\%\end{array}$ & $\begin{array}{c}37.50 \\
\%\end{array}$ & $\begin{array}{l}60 \\
\%\end{array}$ & $\begin{array}{c}66.66 \\
\%\end{array}$ & $\begin{array}{c}33.33 \\
\%\end{array}$ & $25 \%$ & $\begin{array}{l}20 \\
\%\end{array}$ & $\begin{array}{l}40 \\
\%\end{array}$ & $60 \%$ & $\begin{array}{c}37.50 \\
\%\end{array}$ & - \\
\hline
\end{tabular}

Table 6:- Streptopelia decaocto: Showing seasonal trend of drinking behavior.

\begin{tabular}{|c|c|c|c|c|c|c|c|c|c|c|c|c|c|c|}
\hline \multirow[b]{2}{*}{ Season } & \multicolumn{4}{|c|}{ Early Morning } & \multicolumn{3}{|c|}{ Late Morning } & \multicolumn{3}{|c|}{ Noon } & \multicolumn{4}{|c|}{ Afternoon } \\
\hline & $\begin{array}{c}5 \\
\text { to } \\
6 \\
\end{array}$ & $\begin{array}{c}6 \\
\text { to } \\
7 \\
\end{array}$ & 7 to 8 & $\begin{array}{c}8 \text { to } \\
9\end{array}$ & $\begin{array}{c}9 \text { to } \\
10\end{array}$ & $\begin{array}{l}10 \\
\text { to } \\
11 \\
\end{array}$ & $\begin{array}{l}11 \\
\text { to } \\
12 \\
\end{array}$ & $\begin{array}{c}12 \\
\text { to } \\
1 \\
\end{array}$ & $\begin{array}{c}1 \\
\text { to } \\
2 \\
\end{array}$ & $\begin{array}{c}2 \\
\text { to } \\
3 \\
\end{array}$ & 3 to 4 & $\begin{array}{c}4 \text { to } \\
5\end{array}$ & $\begin{array}{c}5 \text { to } \\
6\end{array}$ & 6 to 7 \\
\hline Summer & - & - & $37.50 \%$ & - & - & $50 \%$ & - & - & - & - & - & $45 \%$ & - & - \\
\hline Rainy & - & - & - & $40 \%$ & - & - & - & - & - & - & - & - & $30 \%$ & - \\
\hline Winter & - & - & - & - & $40 \%$ & - & - & - & - & - & $37.50 \%$ & - & - & - \\
\hline
\end{tabular}

Table 7:- Streptopelia decaocto: Showing seasonal trend of resting behavior.

\begin{tabular}{|c|c|c|c|c|c|c|c|c|c|c|c|c|c|c|}
\hline \multirow[b]{2}{*}{ Season } & \multicolumn{4}{|c|}{$\begin{array}{c}\text { Early } \\
\text { Morning }\end{array}$} & \multicolumn{3}{|c|}{ Late Morning } & \multicolumn{3}{|c|}{ Noon } & \multicolumn{4}{|c|}{ Afternoon } \\
\hline & $\begin{array}{l}5 \\
\mathrm{t} \\
0 \\
6\end{array}$ & $\begin{array}{l}6 \\
\mathbf{t} \\
\mathbf{0} \\
7\end{array}$ & $\begin{array}{l}7 \\
\text { t } \\
\text { o } \\
8\end{array}$ & $\begin{array}{l}8 \\
\text { t } \\
\text { o } \\
9\end{array}$ & $\begin{array}{c}9 \\
\text { to } \\
1 \\
0\end{array}$ & $\begin{array}{l}10 \\
\text { to } \\
11\end{array}$ & $\begin{array}{l}11 \\
\text { to } \\
12\end{array}$ & $\begin{array}{l}12 \\
\text { to } 1\end{array}$ & $\begin{array}{c}1 \text { to } \\
2\end{array}$ & 2 to 3 & 3 to 4 & 4 to 5 & 5 to 6 & $\begin{array}{c}6 \text { to } \\
7\end{array}$ \\
\hline $\begin{array}{l}\text { Summe } \\
\mathrm{r}\end{array}$ & - & - & - & - & - & $\begin{array}{l}25 \\
\%\end{array}$ & $\begin{array}{l}50 \\
\%\end{array}$ & $\begin{array}{c}45 \\
\%\end{array}$ & $\begin{array}{l}60 \\
\%\end{array}$ & $\begin{array}{c}37.50 \\
\%\end{array}$ & $\begin{array}{c}12.50 \\
\%\end{array}$ & $\begin{array}{c}37.50 \\
\%\end{array}$ & $\begin{array}{c}62.50 \\
\%\end{array}$ & - \\
\hline
\end{tabular}


Distribution And Daily Activity Of Collared...

\begin{tabular}{|l|l|l|l|l|l|l|l|l|l|l|l|l|l|l|}
\hline Rainy & - & - & - & - & - & - & $\begin{array}{c}20 \\
\%\end{array}$ & - & $\begin{array}{c}30 \\
\%\end{array}$ & $50 \%$ & $70 \%$ & $30 \%$ & $20 \%$ & $\begin{array}{c}30 \\
\%\end{array}$ \\
\hline Winter & - & - & - & - & - & - & $\begin{array}{c}20 \\
\%\end{array}$ & $\begin{array}{c}40 \\
\%\end{array}$ & $\begin{array}{c}60 \\
\%\end{array}$ & $75 \%$ & $\begin{array}{c}66.66 \\
\%\end{array}$ & $20 \%$ & $50 \%$ & - \\
\hline
\end{tabular}

Table 8:- Streptopelia decaocto: Showing seasonal trend of chasing behavior.

\begin{tabular}{|c|c|c|c|c|c|c|c|c|c|c|c|c|c|c|}
\hline \multirow[b]{2}{*}{ Season } & \multicolumn{4}{|c|}{ Early Morning } & \multicolumn{3}{|c|}{ Late Morning } & \multicolumn{3}{|c|}{ Noon } & \multicolumn{4}{|c|}{ Afternoon } \\
\hline & $\begin{array}{l}5 \\
\mathrm{t} \\
\mathrm{o} \\
6 \\
\end{array}$ & $\begin{array}{l}6 \\
\mathrm{t} \\
\mathrm{o} \\
7 \\
\end{array}$ & $\begin{array}{l}7 \\
\text { t } \\
\text { o } \\
8 \\
\end{array}$ & $\begin{array}{c}8 \text { to } \\
9\end{array}$ & 9 to 10 & $\begin{array}{l}10 \\
\text { to } \\
11\end{array}$ & $\begin{array}{l}11 \\
\text { to } \\
12\end{array}$ & 12 to 1 & 1 to 2 & 2 to 3 & $\begin{array}{c}3 \text { to } \\
4\end{array}$ & $\begin{array}{c}4 \text { to } \\
5\end{array}$ & $\begin{array}{c}5 \text { to } \\
6\end{array}$ & 6 to 7 \\
\hline $\begin{array}{l}\text { Summe } \\
\mathrm{r}\end{array}$ & - & - & - & $\begin{array}{l}30 \\
\%\end{array}$ & $\begin{array}{c}37.50 \\
\%\end{array}$ & $\begin{array}{l}25 \\
\%\end{array}$ & $\begin{array}{l}15 \\
\%\end{array}$ & $\begin{array}{c}37.50 \\
\%\end{array}$ & $30 \%$ & $15 \%$ & $\begin{array}{l}25 \\
\%\end{array}$ & $\begin{array}{l}10 \\
\%\end{array}$ & $\begin{array}{l}30 \\
\%\end{array}$ & $\begin{array}{c}33.33 \\
\%\end{array}$ \\
\hline Rainy & - & - & - & $\begin{array}{l}20 \\
\%\end{array}$ & $30 \%$ & $\begin{array}{l}40 \\
\%\end{array}$ & $\begin{array}{l}20 \\
\%\end{array}$ & - & $30 \%$ & $20 \%$ & $\begin{array}{l}25 \\
\%\end{array}$ & $\begin{array}{l}25 \\
\%\end{array}$ & $\begin{array}{l}50 \\
\%\end{array}$ & $30 \%$ \\
\hline Winter & - & - & - & - & $25 \%$ & $\begin{array}{l}40 \\
\%\end{array}$ & $\begin{array}{l}20 \\
\%\end{array}$ & $30 \%$ & $\begin{array}{c}37.50 \\
\%\end{array}$ & $\begin{array}{c}33.33 \\
\%\end{array}$ & $\begin{array}{l}20 \\
\%\end{array}$ & $\begin{array}{l}40 \\
\%\end{array}$ & $\begin{array}{l}40 \\
\%\end{array}$ & - \\
\hline
\end{tabular}

Table 9:- Streptopelia decaocto: Showing seasonal trend of fighting behavior.

\begin{tabular}{|c|c|c|c|c|c|c|c|c|c|c|c|c|c|c|}
\hline \multirow[b]{2}{*}{$\begin{array}{c}\text { Seaso } \\
n\end{array}$} & \multicolumn{4}{|c|}{ Early Morning } & \multicolumn{3}{|c|}{ Late Morning } & \multicolumn{3}{|c|}{ Noon } & \multicolumn{4}{|c|}{ Afternoon } \\
\hline & $\begin{array}{l}5 \\
\mathrm{t} \\
\mathrm{o} \\
6 \\
\end{array}$ & $\begin{array}{l}6 \\
t \\
0 \\
7 \\
\end{array}$ & $\begin{array}{l}7 \\
\text { t } \\
\text { o } \\
8 \\
\end{array}$ & $\begin{array}{c}8 \\
\text { to } \\
9\end{array}$ & $\begin{array}{c}9 \text { to } \\
10\end{array}$ & $\begin{array}{l}10 \\
\text { to } \\
11\end{array}$ & $\begin{array}{l}11 \\
\text { to } \\
12\end{array}$ & $\begin{array}{c}12 \text { to } \\
1\end{array}$ & 1 to 2 & $\begin{array}{c}2 \\
\text { to } \\
3\end{array}$ & 3 to 4 & 4 to 5 & $\begin{array}{c}5 \\
\text { to } \\
6\end{array}$ & $\begin{array}{c}6 \\
\text { to } \\
7\end{array}$ \\
\hline $\begin{array}{l}\text { Summ } \\
\text { er }\end{array}$ & - & - & - & $\begin{array}{l}25 \\
\% \\
\end{array}$ & $\begin{array}{c}37.50 \\
\%\end{array}$ & $\begin{array}{l}40 \\
\% \\
\end{array}$ & $\begin{array}{l}25 \\
\% \\
\end{array}$ & $30 \%$ & $\begin{array}{c}37.50 \\
\% \\
\end{array}$ & $\begin{array}{l}10 \\
\% \\
\end{array}$ & $25 \%$ & $\begin{array}{c}12.50 \\
\%\end{array}$ & $\begin{array}{l}25 \\
\%\end{array}$ & $\begin{array}{l}30 \\
\%\end{array}$ \\
\hline Rainy & - & - & - & $\begin{array}{l}20 \\
\% \\
\end{array}$ & $30 \%$ & $\begin{array}{l}40 \\
\%\end{array}$ & $\begin{array}{c}20 \\
\% \\
\end{array}$ & - & $30 \%$ & $\begin{array}{l}20 \\
\% \\
\end{array}$ & $20 \%$ & $30 \%$ & $\begin{array}{c}40 \\
\% \\
\end{array}$ & $\begin{array}{l}20 \\
\% \\
\end{array}$ \\
\hline Winter & - & - & - & - & $\begin{array}{c}33.33 \\
\%\end{array}$ & $\begin{array}{l}25 \\
\%\end{array}$ & $\begin{array}{c}40 \\
\%\end{array}$ & $\begin{array}{c}33.33 \\
\%\end{array}$ & $25 \%$ & $\begin{array}{l}25 \\
\%\end{array}$ & $\begin{array}{c}37.50 \\
\%\end{array}$ & $25 \%$ & $\begin{array}{l}50 \\
\%\end{array}$ & - \\
\hline
\end{tabular}

Table 10:- Streptopelia decaocto: Showing seasonal trend of vocalization behavior.

\begin{tabular}{|c|c|c|c|c|c|c|c|c|c|c|c|c|c|c|}
\hline \multirow[b]{2}{*}{$\begin{array}{c}\text { Seas } \\
\text { on }\end{array}$} & \multicolumn{4}{|c|}{ Early Morning } & \multicolumn{3}{|c|}{ Late Morning } & \multicolumn{3}{|c|}{ Noon } & \multicolumn{4}{|c|}{ Afternoon } \\
\hline & $\begin{array}{c}5 \text { to } \\
6\end{array}$ & $\begin{array}{c}6 \text { to } \\
7\end{array}$ & $\begin{array}{c}7 \text { to } \\
8\end{array}$ & $\begin{array}{c}8 \\
\text { to } \\
9 \\
\end{array}$ & $\begin{array}{c}9 \text { to } \\
10\end{array}$ & $\begin{array}{l}10 \\
\text { to } \\
11 \\
\end{array}$ & $\begin{array}{l}11 \\
\text { to } \\
12 \\
\end{array}$ & $\begin{array}{c}12 \\
\text { to } 1\end{array}$ & $\begin{array}{c}1 \text { to } \\
2\end{array}$ & $\begin{array}{c}2 \text { to } \\
3\end{array}$ & $\begin{array}{c}3 \text { to } \\
4\end{array}$ & $\begin{array}{c}4 \text { to } \\
5\end{array}$ & $\begin{array}{c}5 \text { to } \\
6\end{array}$ & $\begin{array}{c}6 \text { to } \\
7\end{array}$ \\
\hline $\begin{array}{l}\text { Sum } \\
\text { mer }\end{array}$ & $\begin{array}{c}87.5 \\
0 \% \\
\end{array}$ & $70 \%$ & $50 \%$ & $\begin{array}{l}45 \\
\%\end{array}$ & $\begin{array}{c}37.5 \\
0 \% \\
\end{array}$ & $30 \%$ & $25 \%$ & $\begin{array}{c}12.5 \\
0 \%\end{array}$ & $10 \%$ & $10 \%$ & $\begin{array}{c}12.5 \\
0 \% \\
\end{array}$ & $25 \%$ & $50 \%$ & $\begin{array}{c}62.5 \\
0 \% \\
\end{array}$ \\
\hline $\begin{array}{l}\text { Rain } \\
\mathrm{y}\end{array}$ & - & $80 \%$ & $60 \%$ & $\begin{array}{c}40 \\
\% \\
\end{array}$ & $20 \%$ & $25 \%$ & $\begin{array}{c}12.5 \\
0 \% \\
\end{array}$ & $30 \%$ & $\begin{array}{c}37.5 \\
0 \% \\
\end{array}$ & $\begin{array}{c}12.5 \\
0 \% \\
\end{array}$ & $25 \%$ & $\begin{array}{c}12.5 \\
0 \% \\
\end{array}$ & $25 \%$ & $50 \%$ \\
\hline $\begin{array}{l}\text { Wint } \\
\text { er }\end{array}$ & - & $\begin{array}{c}83.3 \\
3 \%\end{array}$ & $\begin{array}{c}66.6 \\
6 \%\end{array}$ & $\begin{array}{l}50 \\
\%\end{array}$ & $\begin{array}{c}33.3 \\
3 \%\end{array}$ & $\begin{array}{c}37.5 \\
0 \%\end{array}$ & $40 \%$ & $40 \%$ & $25 \%$ & $\begin{array}{c}16.6 \\
6 \%\end{array}$ & $\begin{array}{c}33.3 \\
3 \%\end{array}$ & $25 \%$ & $\begin{array}{c}37.5 \\
0 \%\end{array}$ & - \\
\hline
\end{tabular}




\section{Author Profile (Corresponding Author):-}

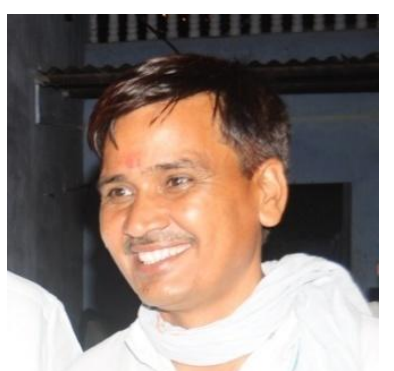

Dr. Maha Singh received the B.Sc. degree in Biology Stream in 1987 and M.Sc. degree in Zoology (Entomology) from Zoology Dept. University of Rajasthan, Jaipur in 1993. During 1996 to July1998 worked as Micro technician in the Department of Zoology, University of Rajasthan Jaipur. Member of Bombay Natural History Society Mumbai. From 1999 to till today worked as Associate Professor of Zoology in Govt. S. K. PG College, Sikar (Rajasthan).

Dr Maha Singh, Lect. In Zoology

P.No. 30, Ramawat Nagar, Kissan Colony

Nawalgarh Road, Sikar (Rajasthan) India 332001

Mob.No. 09414332403 01572-249300 (Res.) 